\title{
ДОСЛІДЖЕННЯ ЕНЕРГЕТИЧНИХ ПАРАМЕТРІВ ПРОЦЕСУ КОНВЕРСІЇ БІОСИРОВИНИ В ЗАКРИТІЙ КАМЕРІ ФЕРМЕНТАЦІЇ
}

\author{
М.Б. Терещук ${ }^{1}$, аспірантка, С.В. Клюс ${ }^{2}$, канд. техн. наук, Н.М. Цивенкова ${ }^{3}$, канд. техн. наук, \\ B.В. Чуба ${ }^{3}$, канд. техн. наук \\ ${ }^{1}$ Поліський національний університет, \\ 10008, Старий бульвар, 7, м. Житомир, Україна. \\ ${ }^{2}$ Інститут відновлюваної енергетики НАН України, \\ 02094, вул. Гната Хоткевича, 20А, м. Київ, Україна. \\ ${ }^{3}$ Національний університет біоресурсів і природокористування України, \\ 03041, вул. Героїв Оборони, 15, м. Київ, Україна.
}

Зброджування біосировини в закритих камерах ферментації є одним з перспективних методів виробнищтва компостів, щзо інтенсивно розвивається. Однак, одним з невирішених питань прочесу зброджування субстратів на основі біосировини 6 закритих камерах є низька ефективність, пов 'язана із втратами енергії. 3 метою дослідження енергетичних параметрів процесу зброджування біосировини розроблено та представлено конструкиію камери ферментації закритого типу. Встановлено, що саме температурний режим на кожній з фаз зброджування субстрату є вагомим чинником впливу на ефективність усього прочесу виробництва компосту. Експериментально визначено, що оптимальними температурами на кожній з фаз зброджування є: фаза розігрівання субстрату - до $20{ }^{\circ} \mathrm{C}$; мезофільна фаза - від 20 до $42{ }^{\circ} \mathrm{C}$; термофільна фаза - від 42 до $65^{\circ} \mathrm{C}$; фаза дозрівання - від $65^{\circ} \mathrm{C}$ до температури навколишнього середовища. Забезпечення вказаного температурного режиму на кожній з фаз зброджування дозволяє зробити проиес компостування керованим та отримувати компости високої якості відповідно до біотехнологічних норм. Експериментально досліджено, щзо найбільше енергї втрачається через конвекцію на термофільній фазі компостування. Найвищі значення коефіцієнту конвекційного теплообміну становили $1,6 \ldots 1,7 \mathrm{Bm} /\left(\mathrm{M}^{2}{ }^{\circ} \mathrm{C}\right)$ при температурі процесу рівній $61 \ldots 62{ }^{\circ} \mathrm{C}$ i мали місие на $108 \ldots 132-и ̆$ годинах тривання процесу компостування. При иьому на 132-й годині тривання процесу значення коефіцієнта тепловиділення становило 8,5 Вт на кілограм органічної речовини субстрату, а сумарна кількість теплоти, виділена з кілограму органічної речовини субстрату, досягала 2 МДж/кг. Хоча під час термофільної фази компостування біосировини внутрішня енергія субстрату різко зростала, на забезпечення енергетичних потреб прочесу витрачалося лише 5 \% иієї енергії. Аналіз параметрів процесу свідчить, щз близько $95 \%$ від виробленої в прочесі компостування теплоти втрачається через конвекиію, теплове випромінювання та під час аерації субстрату повітрям. Ці втрати можна зменшити, розробивши відповідні термопідтримуючі засоби - теплоізоляційне покриття зовнішніх поверхонь камер, використання нагрівачів. Бібл. 14, рис. 5.

Ключові слова: біохімічна конверсія, біосировина, реактор барабанного типу, субстрат, компост.

\section{INVESTIGATION OF ENERGY PARAMETERS OF BIOMATERIAL CONVERSION PROCESS IN CLOSED FERMENTATION CHAMBER} \author{
V. $\mathbf{C h u b a}^{3}$, candidate of technical science \\ ${ }^{1}$ Polissia National University, \\ 10008, 7 Stary Blvd., Zhytomyr, Ukraine. \\ ${ }^{2}$ Institute of Renewable Energy of the National Academy of Sciences of Ukraine, \\ 02094, 20A Hnata Khotkevycha St., Kyiv, Ukraine. \\ ${ }^{3}$ National University of Life and Environmental Sciences of Ukraine, \\ 03041, 15 Heroyiv Oborony St., Kyiv, Ukraine.
}

M. Tereshchuk ${ }^{1}$, postgraduate student, $\mathbf{S}$. Klius ${ }^{2}$, candidate of technical science, $\mathbf{N}$. Tsyvenkova ${ }^{3}$, candidate of technical science,

Fermentation of bio-raw materials in closed fermentation chambers is one of the promising methods of composting production, which is developing intensively. However, one of the unresolved issues in the fermentation of bio-based substrates in closed chambers is the low efficiency associated with energy losses. In order to study the energy parameters of the fermentation process of bio raw materials, the design of a closed fermentation chamber was developed and presented. It is established that the temperature parameters at each of the fermentation phases of the substrate are an important factor influencing the efficiency of the entire compost production. It is experimentally determined that the optimal temperatures at each of the fermentation phases are: the phase of heating the substrate -

(C) М.Б. Терещук, С.В. Клюс, Н.М. Цивенкова, В.В. Чуба, 2021

Відновлювана енергетика. 2021. № 1 
up to $20^{\circ} \mathrm{C}$; mesophilic phase - from 20 to $42{ }^{\circ} \mathrm{C}$; thermophilic phase - from 42 to $65{ }^{\circ} \mathrm{C}$; ripening phase - from $65{ }^{\circ} \mathrm{C}$ to ambient temperature. Providing the specified temperature regime at each of the fermentation phases allows to make the composting process manageable and to obtain high quality composts in accordance with biotechnological norms. It has been experimentally investigated that most energy is lost due to convection in the thermophilic phase of composting. The highest values of the convective heat transfer coefficient were $1.6 \ldots 1.7 \mathrm{~W} /\left(\mathrm{m}^{2} \cdot{ }^{\circ} \mathrm{C}\right)$ at the process temperature equal to $61 \ldots 62{ }^{\circ} \mathrm{C}$ and took place at $108 \ldots 132$ hours of the composting process. At the 132nd hour of the process, the value of the heat transfer coefficient was $8.5 \mathrm{~W}$ per kilogram of organic matter of the substrate, and the total amount of heat released from a kilogram of organic matter of the substrate reached $2 \mathrm{MJ} / \mathrm{kg}$. Although the internal energy of the substrate increased sharply during the thermophilic phase of composting of raw materials, only $5 \%$ of this energy was used to meet the energy needs of the process. Analysis of process parameters shows that about $95 \%$ of the heat produced during composting is lost through convection, thermal radiation and during aeration of the substrate with air. These losses can be reduced by developing appropriate thermal support: thermal insulation of the outer surfaces of the chambers, the use of heaters. Ref. 8, fig. 4.

Keywords: biochemical conversion, bio raw materials, drum reactor, substrate, compost.

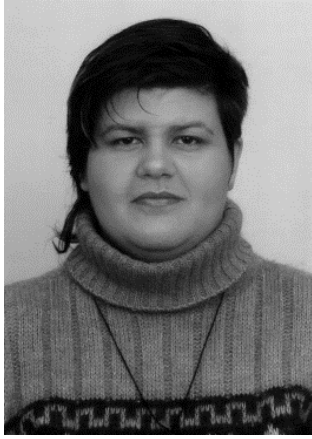

М.Б. Терешук M. Tereshchuk

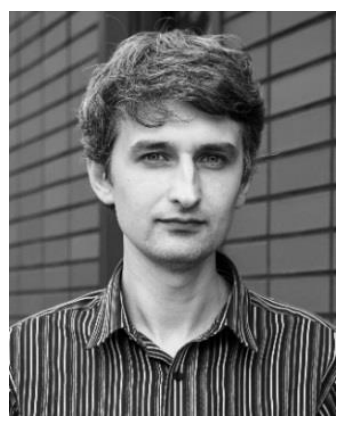

C.B. Клюс S. Klius

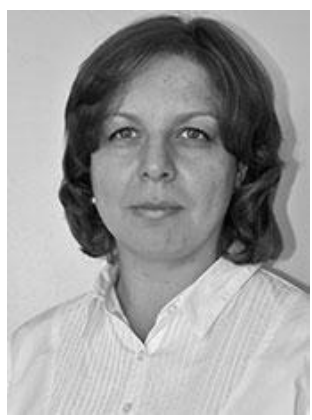

H.М. Цивенкова N. Tsyvenkova
Відомості про автора: аспірантка кафедри механіки та інженерії агроекосистем Поліського національного університету Освіта: Житомирський національний агроекологічний університет Наукова сфера: конверсія біомаси сільськогосподарського походження в закритих камерах

Публікації: 20 публікацій, (зокрема 4 наукові праці, опубліковані у вітчизняних виданнях, 6 - у міжнародних рецензованих фахових виданнях і 10 тез конференцій) ORCID: 0000-0002-3020-4528

Контакти: тел./факс: +38(093)102-06-76 e-mail: marischa3127@gmail.com

Відомості про автора: завідувач відділу відновлюваних органічних енергоносіїв Інституту відновлюваної енергетики НАН України, кандидат технічних наук (2016 рік) Освіта: Сумський державний університет, магістр обладнання хімічних виробництв та підприємств будівельних матеріалів

Наукова сфера: біоенергетика, газифікація біомаси, переробка органічних відходів Публікації: понад 30 наукових публікацій, зокрема 11 патентів

ORCID: 0000-0002-5804-4925

Контакти: тел./факс: +38(044)206-28-09 e-mail: biomassa@ukr.net

Відомості про автора: доцент кафедри тракторів, автомобілів та біоенергосистем Національного університету біоресурсів і природокористування України, кандидат технічних наук

Наукова сфера: енергозбереження, альтернативна енергетика, біоенергетичні системи і комплекси

Публікації: 108 друкованих праць (зокрема 48 статей у фахових виданнях України, 14 статей у збірниках, що входять до Міжнародної бази Scopus/WoS)

ORCID: 0000-0003-1703-4306

Контакти: tel./fax: +38(050)313-89-03 e-mail: nataliyatsyvenkova@gmail.com
Author information: Zhytomyr National Agroecological University, Ph.D, graduate student of the Mechanics and agroecosystems engineering Department

Education: Zhytomyr National Agroecological University

Research area: organic waste utilization Publications: 20 scientific publications, including 10 conference proceedings ORCID: 0000-0002-3020-4528

Contacts: tel./fax: $+38(093) 102-06-76$ e-mail: marischa3127@gmail.com

Author information: Institute of Renewable Energy of NAS of Ukraine, head of bioenergy department, PhD since 2016

Education: Sumy State University, master of equipment of chemical productions and building materials enterprises

Research area: bioenergy, gasification of biomass, organic waste utilization Publications: more than 30 scientific publications, including 11 patents ORCID: 0000-0002-5804-4925

Contacts: tel./fax: +38(044)206-28-09 e-mail: biomassa@ukr.net

Author information: National University of Life and Environmental Sciences of Ukraine, Ph.D, assis. prof., the Tractors, Automobiles, and Bioenergy Systems Department, Mechanical and Technological faculty

Research area: energy saving, alternative energy, bionergetic systems and complex Publications: 108 scientific papers (including 48 scientific papers, which are published in Ukrainian peer-reviewed journals, and 14 - in Scopus/WoS)

ORCID: 0000-0003-1703-4306

Contacts: tel./fax: $+38(050) 313-89-03$

e-mail: nataliyatsyvenkova@gmail.com 


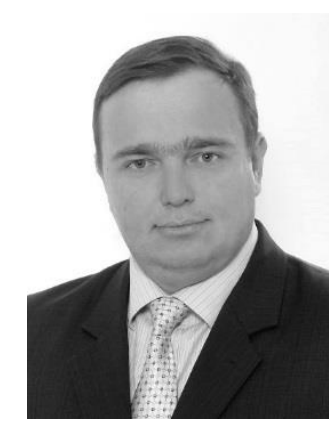

B.В. Чуба V. Chuba
Відомості про автора: в.о. завідувача кафедри тракторів, автомобілів та біоенергосистем Національного університету біоресурсів та природокористування України, кандидат технічних наук, доцент Наукова сфера: біоенергетичні системи аграрного виробництва, виробництво i використання біопалива з рослинної біомаси Публікації: 114 наукових публікацій, 3 них 27 входять до наукометричної бази Scopus, 19 патентів на винаходи та корисні моделі, співавтор двох навчальних посібників та п'яти монографій

ORCID: 0000-0002-4119-0520

Контакти: tel./fax: +38(095)277-71-10 e-mail: vvchuba@ukr.net
Вступ. Процес біохімічної конверсії залишків сільськогосподарського виробництва (компостування) $€$ найбажанішим методом поводження 3 органічними відходами [10]. Традиційні системи аеробного компостування поділяються на відкриті й закриті, з примусовою пневматичною (напірною, відсмоктувальною), механічною чи комбінованою системою аерації. Відкриті системи потребують значних площ, а тривалість процесу компостування середньому триває $2-4$ роки $[2,12]$.

Одним 3 напрямів розвитку засобів для здійснення процесу компостування біосировини $\epsilon$ створення конструкцій закритих камер ферментації, найпоширеніші $з$ яких $є$ реактори барабанного типу. Такі реактори здатні за відносно короткий термін переробляти значну кількість відходів, не потребують великих площ для монтажу, можуть бути оснащені обладнанням для здійснення контролю параметрів процесу (якот температура, вологість субстрату, об'єм і швидкість потоку повітря, необхідного для аераціï) $[5,7,13]$.

Процес ферментації в закритих камерах $\epsilon$ перспективною технологією, а використання реакторів барабанного типу для реалізації цього процесу забезпечує рівномірність змішування компонентів субстрату в процесі ферментації, а також позбавлення схожості насіння бур'янів та знезараження патогенної мікрофлори. Як наслідок, вироблений кінцевий продукт має високі показники за вмістом азоту, калію та фосфору [9]. Тривалість процесу компостування в біореакторах різко скорочується до $2 \ldots 3$ тижнів
Author information: National University of Life and Environmental Sciences of Ukraine, Ph.D, head of Tractors, Automobiles, and Bioenergy Systems Department, Mechanical and Technological faculty

Research area: bioenergy systems, agroecosystems technical support, biofuels Publications: 114 scientific publications, of which 27 in Scopus referred journals, 19 patents models, co-author of two textbooks and 5 monographs

ORCID: 0000-0002-4119-0520

Contacts: tel./fax: +38 (095) 277-71-10

e-mail: vvchuba@ukr.net
$[1,9]$. Оскільки переважна більшість аграрних підприємств має надлишок рослинної сировини лише в кінці сезону збору врожаю, то в сільськогосподарській практиці широкого розповсюдження набули установки періодичної дії. Для підприємств, які мають кілька напрямів діяльності - рослинництво, тваринництво, птахівництво тощо, - доцільним $\epsilon$ використання реакторів безперервної дії. В таких реакторах також передбачено змішування свіжого матеріалу 3 переробленим субстратом [8].

Перші зразки реакторів барабанного типу оберталися вручну з інтервалом у 6, 12, 18 і 24 години. Вплив частоти обертання та часового інтервалу між операціями обертання реактора на ефективність виробництва компостів представлено в роботі [3]. Однак дослідження ефективності процесу компостування біосировини в реакторах, за умови періодичної аерації субстрату, з погляду втрат теплоти не здійснювалися.

Під час процесу компостування біосировини завдяки метаболічній активності мікроорганізмів виділяється значна кількість теплоти, яка приводить до підвищення температури субстрату до $60-75^{\circ} \mathrm{C}$ [11]. Тому дослідження енергетичних параметрів процесу компостування мають важливе значення для здійснення керування ним і контролю процесу 3 метою його оптимізації. Дослідники стверджують, що за рахунок оптимізації робочих параметрів під час термофільного режиму можна зменшити тривалість процесу компостування й отримати компост з високими показниками якості 
відповідно до біотехнологічних норм [13]. Також зазначено, що температурний режим в межах 52$65^{\circ} \mathrm{C}$ сприяє найвищій термофільній активності процесу [4]. Відповідно кількісна оцінка виробленої та витраченої в процесі компостування теплоти $є$ ключовим фактором керування процесом та підвищення продуктивності біореактора.

На жаль, енергетичні параметри процесу компостування досліджені недостатньо. Відомо, що в процесі компостування соломи пшениці виділяється 17 МДж теплоти 3 кілограма органічних речовин вмісту субстрату; в процесі компостування пташиного посліду - близько 13 МДж; в процесі компостування суміші зелених рослин $з$ деревною стружкою і твердими міськими біовідходами - 570 кДж 3 кілограма сухої деградованої маси; суміші з вмістом гною ВРХ, деревної стружки та пташиного посліду 16...20 МДж 3 кілограму леткої твердої речовини субстрату; комунальних відходів - близько 1,2 МДж 3 кілограма деградованої речовини; суміші з вмістом листя дерев, промислового мулу, рідких відходів та стічних вод - 7...10 МДж 3 кілограма деградованої органічної речовини [11].

Однак дослідження інших авторів $[4,11,13]$ стосувалися оцінки виділеної кількості теплоти під час компостування біосировини в нерухомих реакторах. Питання визначення втрат теплоти в процесі компостування майже не розглядалося. Найвищі значення втрат теплоти через стінки реактора барабанного типу спостерігалися під час дослідження лабораторного зразка установки, тоді як найвищі втрати теплоти 3 вологою, що випаровується, відповідали параметрам реактора промислового зразка [6]. Інтенсивність тепловиділення в процесі компостування $\epsilon$ складною функцією багатьох змінних, зокрема хімічних, фізичних і біологічних властивостей компостованого матеріалу. Цим обумовлений великий діапазон значень кількості теплоти $(0,5 \ldots 20$ МДж/кг), яка виділяється в процесі розкладання органічного матеріалу. Звідси високі втрати сумарної кількості теплоти, які можуть становити від 30 до $90 \%$ загальної кількості виробленої теплоти $[6,11]$. Крім того, в попередніх дослідженнях розглянуто нерухомі реактори барабанного типу, для яких визначалася сумарна кількість виробленої теплоти і втрати теплоти в процесі компостування. Однак інформація щодо утвореної в процесі компостування біосировини теплоти і теплових втрат для реакторів, які обертаються на низьких частотах, досі відсутня.

Отже, необхідно провести дослідження енергетичних параметрів процесу біохімічної конверсії біосировини в закритій камері ферментації з метою підвищення ефективності процесу.

Така інформація $\epsilon$ важливою для виробників обладнання з переробки біосировини на якісні компости і добрива.

Мета i завдання дослідження. Метою дослідження $€$ визначення енергетичних параметрів процесу біохімічної конверсії біосировини в закритій камері ферментації. Це забезпечить можливість підвищення ефективності процесу виробництва компостів.

Для досягнення поставленої мети необхідно було виконати такі завдання:

- встановити залежність температури процесу компостування біосировини від частоти обертання закритої камери ферментації та тривалості перебігу процесу;

- дослідити залежність коефіцієнта конвекційного теплообміну від тривалості перебігу процесу й температури процесу компостування;

- дослідити залежність кількості накопиченої теплоти й коефіцієнта тепловиділення від температури процесу компостування і тривалості перебігу процесу;

- дослідити залежність загальної кількості виділеної енергії та внутрішньої енергії переробленого субстрату від тривалості перебігу процесу.

$\begin{array}{ccr}\text { Матеріали } & \text { i } \begin{array}{r}\text { методи } \\ \text { енергетичних }\end{array} & \text { дослідження } \\ \text { параметрів } & \text { реактора }\end{array}$

барабанного типу. 3 метою експериментального дослідження енергетичних параметрів процесу компостування біосировини сільськогосподарського походження був розроблений та виготовлений експериментальний реактор барабанного типу (рис. 1) [5]. Загальна вага незавантаженої установки - 92 кг, радіус барабана - 275 мм, а довжина - 70 мм. 


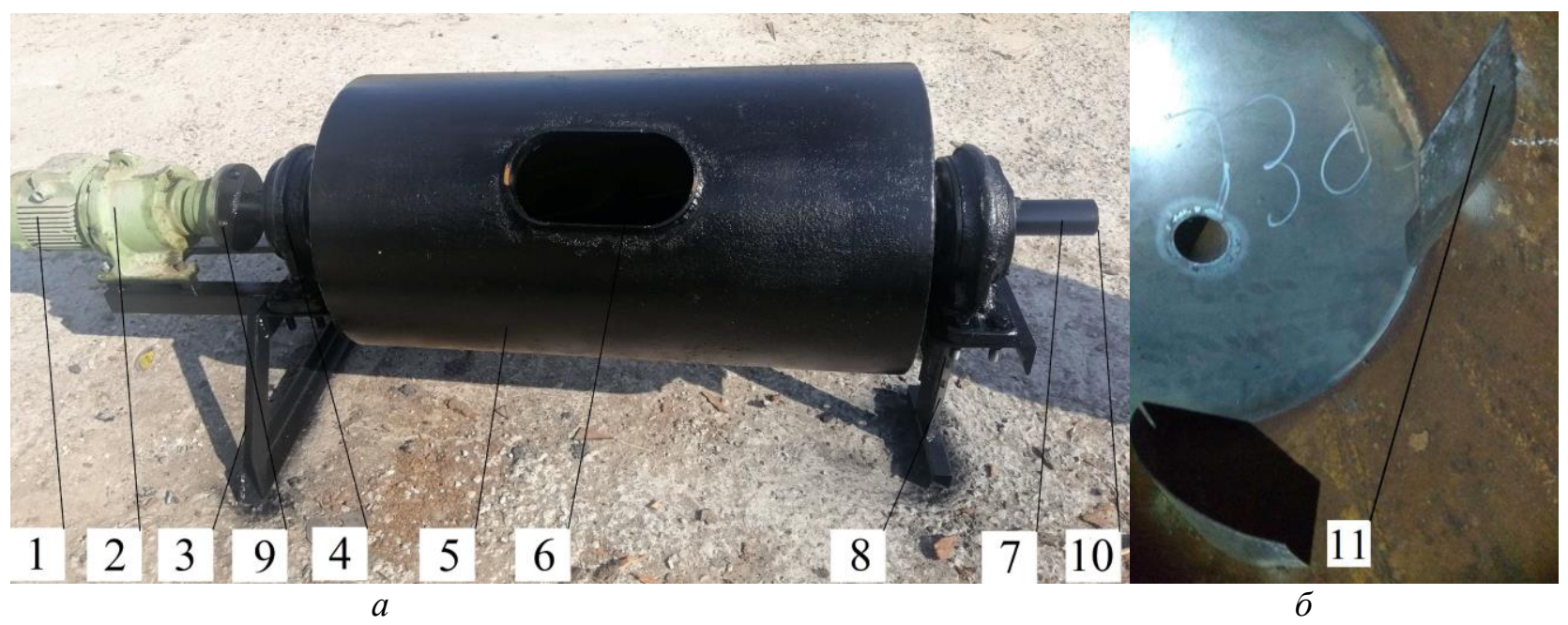

Рис. 1. Дослідна установка: а - загальний вигляд реактора барабанного типу; б - встановлення лопатей [5]: 1 - електродвигун; 2 - редуктор; 3 - рама; 4 - опора підшипникова; 5 - корпус реактора; 6 - люк завантажувальний; 7 - вісь; 8 - стійка регульована; 9 - муфта з'єднувальна; 10 - штуцер із внутрішньою різьбою; 11 - стаціонарно закріплені лопаті (трубки з форсунками знято)

Fig. 1. Experimental installation: $a$ - general view of a drum type reactor; $b$ - blades installation [5]: 1 - electric motor; 2 - gear; 3 - frame; 4 -bearing support; 5 - reactor; 6 - loading lid; 7 - axle; 8 - regulated stand; 9 - coupling; 10 - connector with inner threads; 11 - blades (pipes with jets unmounted)

Для досліджень було використано субстрат, що складався із $50 \%$ суміші підстилкового гною та січки соломи (загальною вологістю $45 \%), 20 \%$ пташиного посліду та $30 \%$ рослинних матеріалів (15\% торфу та $15 \%$ тирси дерев листяних порід) [5]. Завантаження субстрату й вивантаження компосту здійснювалося періодично, що для дослідної установки є припустимим. Субстрат перемішували протягом 5 хв через кожні 55 хв.

Проби перемішаних компонентів субстрату відбирались трубчастим пробовідбірником у різних точках барабана при знятій кришці на кожному 3 етапів компостування. Вологість субстрату вимірювали приладом ZD-05 (Японія) відповідно до вимог стандарту EN 14774-2:2009. Маса проби визначалася за допомогою терезів лабораторних FEH-320 («Укрваги», Україна). Температуру субстрату вимірювали датчиком температури ТСП 1-8 (ПАТ «Тера», Україна). Частоту обертання барабана реактора вимірювали портативним оптичним тахометром testo 465 (Німеччина).

Одержані результати експериментальних досліджень опрацьовували із застосуванням пакета прикладних програм Microsoft Excel 2003 та Statistica 11.0 (StatSoft, СШA) згідно 3 описаною методикою [14].

\section{Результати експериментального} дослідження енергетичних параметрів процесу компостування біосировини в реакторі барабанного типу. Завдяки метаболічним процесам, що відбуваються під час компостування в субстраті, в реакторі виділяється значна кількість теплоти. Залежність, яка характеризує зміну температури субстрату протягом процесу компостування на кожному 3 етапів, представлена на рис. 2. 


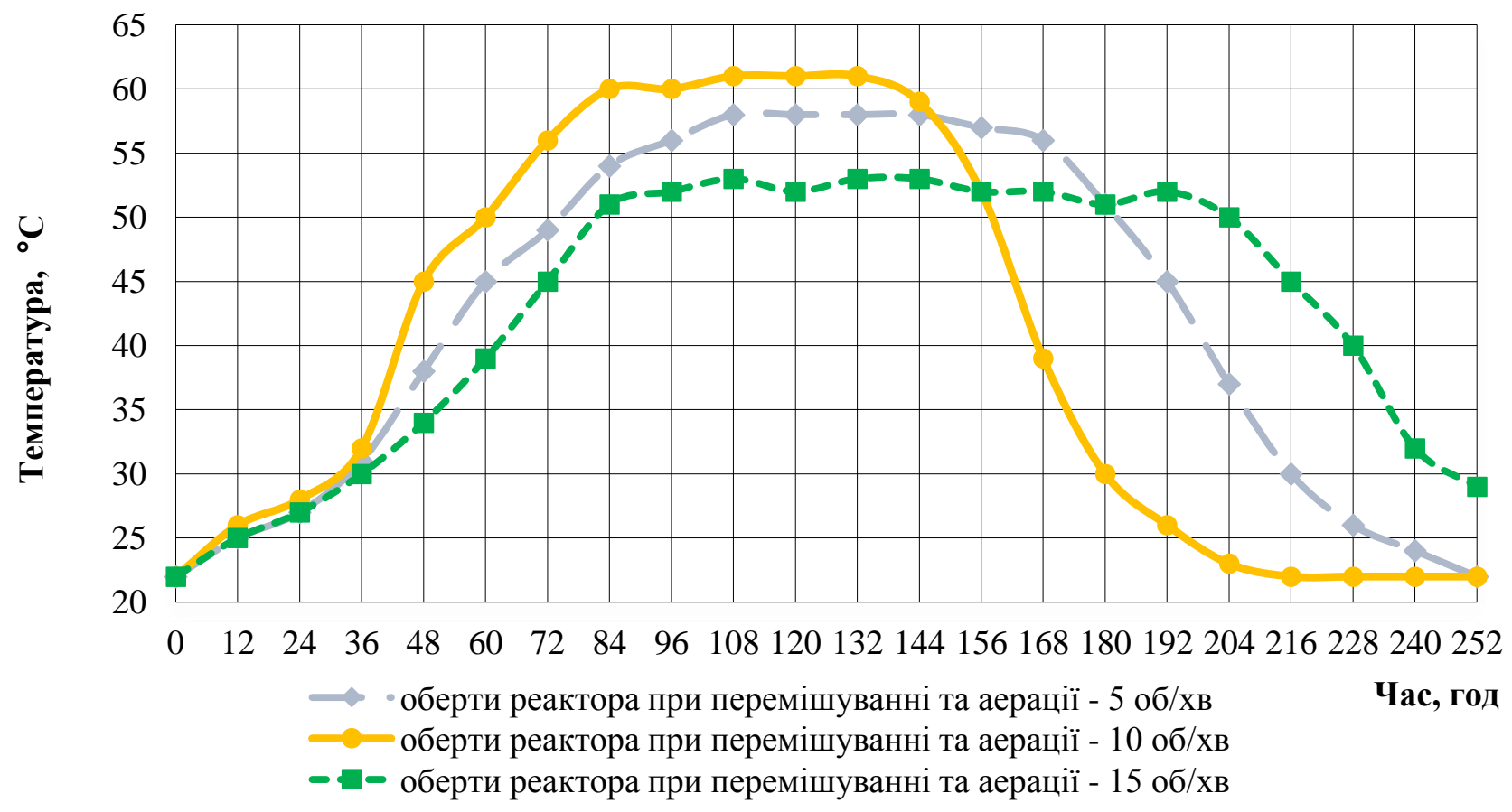

Рис. 2. Залежність температури процесу компостування біосировини від тривалості перебігу процесу

Fig. 2. Dependence of the temperature of biomaterials composting process on the process duration.

На рис. 2 можна виділити чотири температурні зони, які відповідали певним фазам процесу компостування субстрату з біосировини. В інтервалі часу від 0 до 36 год (перший етап компостування) відбувається повільне розігрівання субстрату до температури $30^{\circ} \mathrm{C}$. Використання режиму перемішування субстрату 3 одночасною аерацією не впливає на перебіг процесу компостування і не змінює температуру процесу. Мезофільна фаза характеризується температурним режимом від 30 до $42{ }^{\circ} \mathrm{C}$ і протікає на 36 - 72-й годині тривалості процесу залежно від частоти обертання реактора.

На другому етапі температура субстрату стрімко зростає, досягаючи значення $50{ }^{\circ} \mathrm{C}-$ початок термофільної фази процесу компостування біосировини. Дана фаза характеризується інтенсивним нагріванням субстрату, чому сприяє режим перемішування 3 аерацією: при частоті обертання реактора 5 об/хв температура початку термофільного режиму становила $50{ }^{\circ} \mathrm{C}$ вже на 72-й годині тривалості процесу компостування; при частоті обертання реактора 10 об/хв - на 60-й годині тривалості процесу i при частоті обертання реактора 15 об/хв - на 84-й годині тривалості процесу.

На третьому етапі компостування субстрату температура процесу відповідала термофільній фазі з характерною за часом тривалістю. Залежно від частоти обертання реактора отримано такі результати: при частоті обертання реактора 5 об/хв температура термофільної фази становила $55 \ldots .58^{\circ} \mathrm{C}$, а ії тривалість була 108 год; при частоті 10 об/хв температура становила $60 \ldots 61^{\circ} \mathrm{C}$, а тривалість - 98 год; при частоті 15 об/хв температура становила $51 \ldots 53{ }^{\circ} \mathrm{C}$, а тривалість 120 год.

На четвертому етапі компостування (фаза дозрівання) температура субстрату падала нижче $30{ }^{\circ} \mathrm{C}$, що свідчило про закінчення процесу ферментації.

Як видно на рис. 2, забезпечення оптимального режиму змішування та аерації (частота обертання 10 об/хв) сприяло зростанню температури процесу на всіх етапах компостування біосировини та дало змогу зменшити час компостування субстрату на $16,7-27,4 \%$. 
В процесі дослідження також вимірювали температуру внутрішньої поверхні стінок реактора. Протягом перших 60 год роботи реактора поверхня внутрішніх стінок реактора майже дорівнювала температурі субстрату. Однак в кінці процесу компостування (з 216-ї до 252-ї години) максимальна різниця температур внутрішніх стінок реактора і компосту становила близько $4{ }^{\circ} \mathrm{C}$. Відповідно для виконання подальших досліджень параметром термостійкості внутрішніх поверхонь реактора можна знехтували, не ставлячи під загрозу точність проведення експерименту.

Залежність коефіцієнта конвекційного теплообміну від тривалості перебігу процесу представлена на рис. 3.

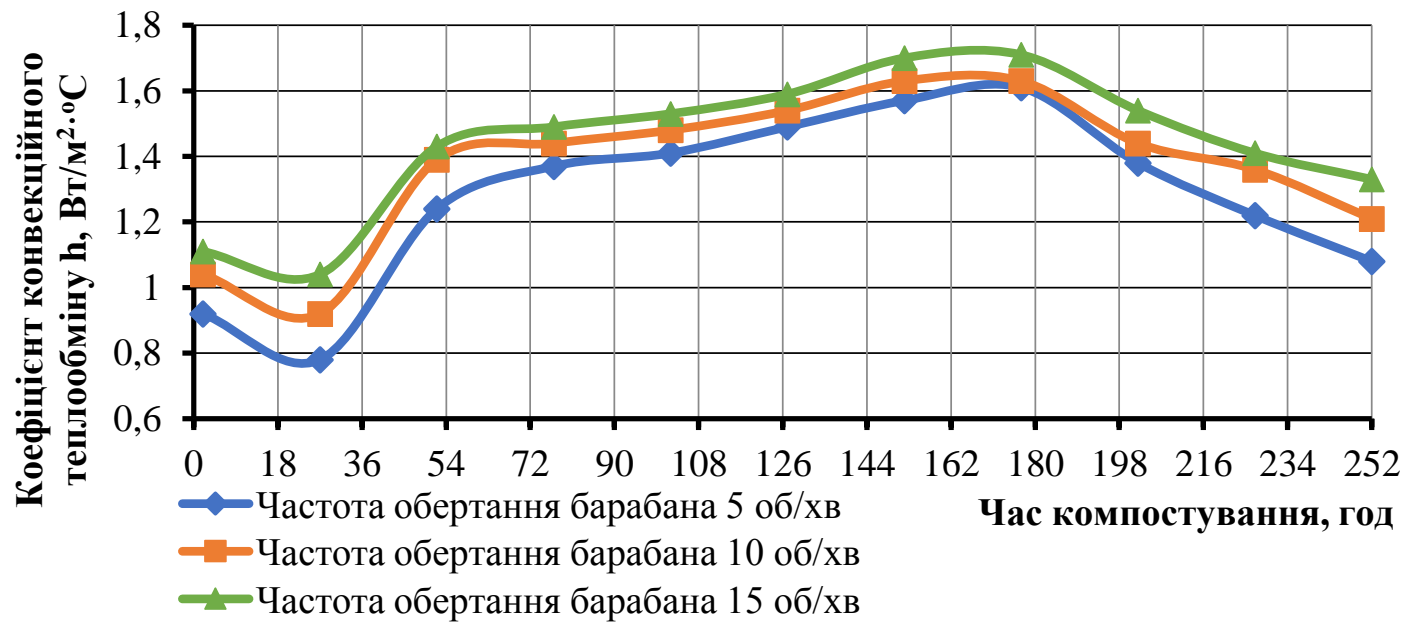

Рис. 3. Залежність коефіцієнта конвекційного теплообміну від тривалості перебігу процесу

Fig. 3. Dependence of the convective heat transfer coefficient on the process duration

Як видно на рис. 3, найвищі значення коефіцієнта конвекційного теплообміну $1,6 \ldots 1,7 \mathrm{BT} /\left(\mathrm{M}^{2} \cdot{ }^{\circ} \mathrm{C}\right)$ були характерними для найвищих значень температури компостування $61 \ldots 62^{\circ} \mathrm{C}$ (термофільний режим) на 108...132-й годині протікання процесу компостування біосировини.
На рис. 4 наведено залежність кількості накопиченої теплоти й коефіцієнта тепловиділення від тривалості перебігу процесу компостування біосировини в реакторі барабанного типу.

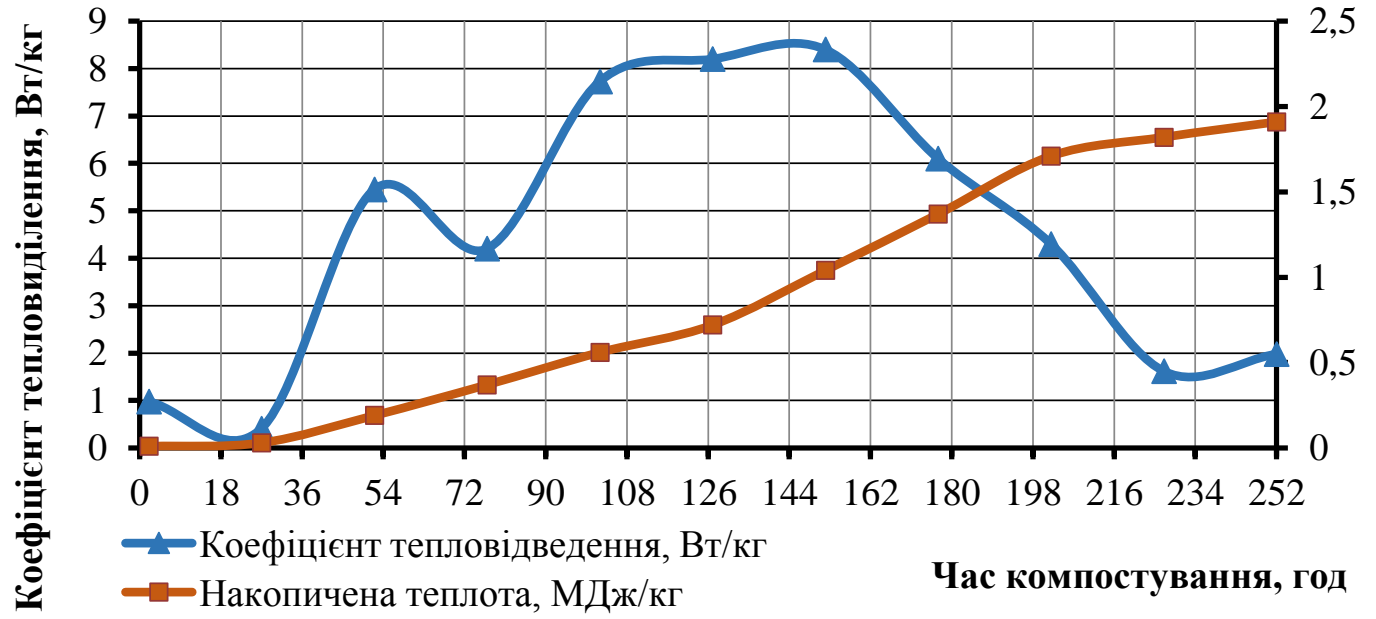

Рис. 4. Залежність кількості накопиченої теплоти і коефіціснта тепловиділення від тривалості перебігу процесу

Fig. 4. Dependence of the cumulated heat and heat dissipation coefficient the on the process duration 
Оскільки

внаслідок

протікання

метаболічних реакцій виділялася теплота, температура субстрату, який зброджувався, зростала, досягаючи максимального значення $62{ }^{\circ} \mathrm{C}$. Найвище значення коефіцієнта тепловиділення при цьому становило 8,5 Вт на кілограм органічної речовини субстрату і було отримано на 132-й годині протікання процесу компостування. Загалом сумарна кількість теплоти, яка виділялася 3 кілограма органічної речовини субстрату, досягала 2,0 МДж/кг.

Виділення теплоти внаслідок протікання біохімічних реакцій залежить від кількох параметрів процесу, як-от: рівномірність розподілу вологості в субстраті, ефективність процесу змішування та аерації, концентрація кисню та азоту тощо. Зниження коефіцієнта тепловиділення спостерігається на 20-й і 75-й годинах роботи (див рис. 4). Різке зниження температури зброджуваного субстрату спостерігалося, коли температура досягала свого максимального значення - починалася фаза дозрівання. Дана температура була вищою за оптимальне значення температури термофільного режиму, тому ріст і активність мікроорганізмів уповільнювалися. Як наслідок, швидкість виділення теплоти, а також температура переробленого субстрату різко знижувалися. Іншою причиною зниження температури переробленого субстрату $є$ те, що споживання біодоступних поживних речовин мікроорганізмами зменшує метаболічну реакцію [6].

Для лабораторних зразків реакторів барабанного типу втрати теплоти є тим вищими, чим вищим $є$ відношення площі поверхні реактора до його об'єму $[6,11]$. Втрати теплоти конвекцією i випромінюванням через зовнішні поверхні реакторів становлять 60-90 \% загальної кількості втрат теплоти [6, 11].

Залежність загальної кількості виділеної в процесі компостування енергії та внутрішньої енергії переробленого субстрату від тривалості перебігу процесу компостування наведена на рис. 5.

Під час досліджень реактора барабанного типу (див. рис. 1) близько $95 \%$ виробленої в процесі компостування теплоти виділялося в оточуюче середовище шляхом конвекції, теплового випромінювання та під час аерації. Більша частина теплових втрат (97\% загальних втрат) спричинена конвекцією через зовнішні поверхні реактора (з них 69 \% через циліндричний корпус та $28 \%$ через торцеві поверхні). I лише $2 \%$ теплоти втрачалося під час одночасного процесу змішування з аерацією. Незначні втрати теплоти (1\% загальних $\quad$ втрат) пов'язані 3 середовищем, яке оточує реактор - температура стін лабораторії, температура повітря в лабораторії тощо. Коли реактор експлуатувався на відкритому повітрі, втрати теплоти були на $10 \ldots 19 \%$ вищими (для теплого періоду року), оскільки зовнішня поверхня реактора обмінювалася теплотою з довкіллям, температура якого значно нижча за температуру повітря в лабораторії.

На рис. 5 представлено залежність загальної кількості виділеної енергії та внутрішньої енергії переробленого субстрату від тривалості перебігу процесу компостування. 


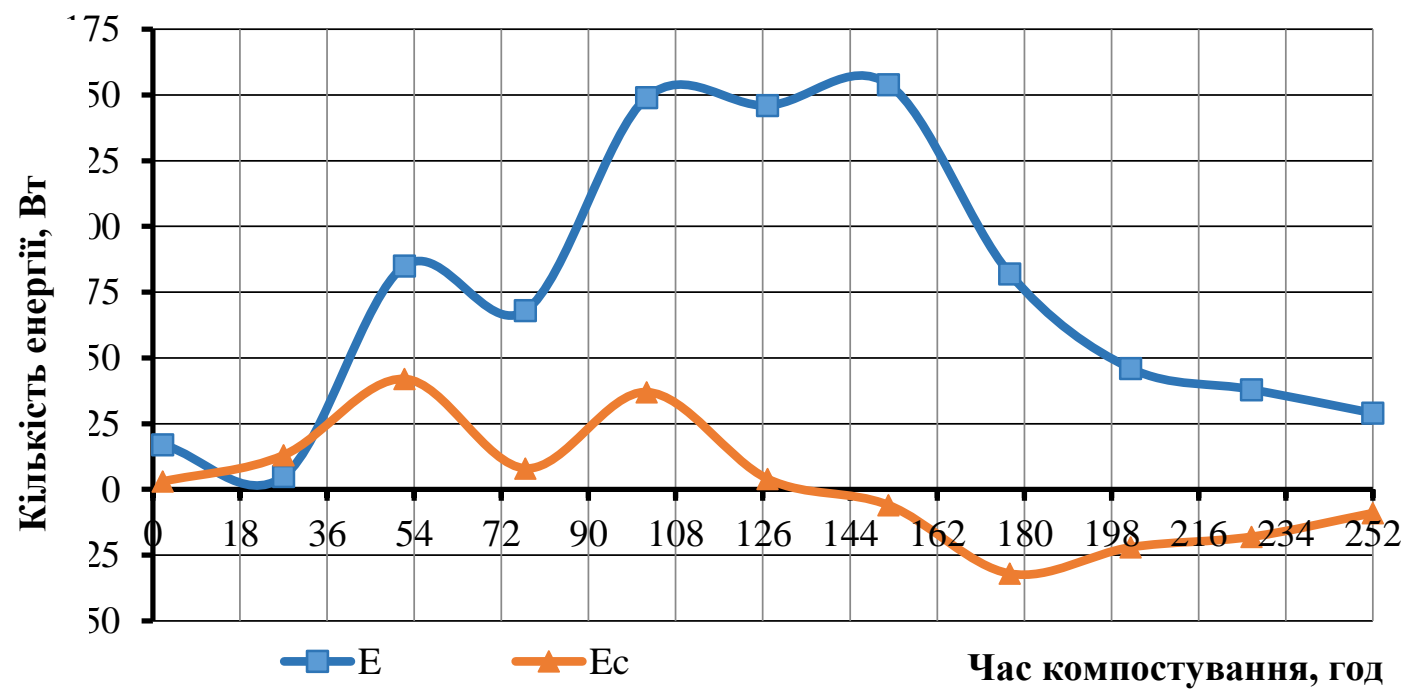

Рис. 5. Залежність загальної кількості виділеної енергії та внутрішньої енергії переробленого субстрату від тривалості перебігу процесу

Fig. 5. Dependence of the total amount of process generated energy and internal energy of the processed substrate on the process duration

Швидкість зміни внутрішньої енергії значною мірою залежить від кількості виділеної в процесі компостування енергії та від внутрішньої енергії переробленого субстрату. В період термофільної фази компостування внутрішня енергія субстрату різко зростала, тоді як в період фази дозрівання, навпаки, - зменшувалася. Перероблений субстрат отримував лише близько $5 \%$ теплоти у вигляді внутрішньої енергії.

\section{Висновки:}

1. Здійснено аналітичний огляд робочих параметрів процесу компостування біосировини сільськогосподарського походження. Встановлено, що на ефективність процесу компостування впливає температурний режим, який в свою чергу залежить від частоти обертання реактора, режиму аерації повітрям, рівномірності розподілу вологості в субстраті, вмісту кисню та азоту в субстраті тощо. 3 метою забезпечення оптимального температурного режиму процесу компостування потрібно визначити кількість теплоти, яка надходить, виділяється i витрачається в процесі компостування.

2. В процесі компостування біосировини було чітко виділено чотири температурні зони, які відповідали певним фазам процесу: фаза розігрівання субстрату - до $20^{\circ} \mathrm{C}$ (тривалість фази від 0 до 36 год); мезофільна фаза $-20 \ldots 45{ }^{\circ} \mathrm{C}$ (тривалість фази - від 36 до 60 год); термофільна фаза - 45...65 ${ }^{\circ} \mathrm{C}$ (тривалість фази - 98 год); фаза дозрівання - температура субстрату зменшується майже до температури навколишнього середовища, що свідчить про завершення процесу компостування. Фази компостування наведено для оптимальної частоти обертання реактора, рівної 10 об/хв.

3. Найвищі значення коефіцієнта конвекційного теплообміну $1,6 \ldots 1,7 \mathrm{BT} /\left(\mathrm{M}^{2 .}{ }^{\circ} \mathrm{C}\right)$ були характерними для температури компостування $61 \ldots 62{ }^{\circ} \mathrm{C}$ (термофільний режим) на $108 \ldots 132-$-й годині тривання процесу компостування біосировини.

4. Найвище значення коефіцієнта тепловиділення при температурі $62{ }^{\circ} \mathrm{C}$ становило 8,5 Вт на кілограм органічної речовини субстрату i було отримане на 132-й годині протікання процесу компостування. Загалом сумарна кількість теплоти, яка виділялася 3 кілограма органічної речовини субстрату, досягала 2,0 МДж/кг.

5. Швидкість зміни внутрішньої енергії значною мірою залежить від кількості виділеної в процесі компостування енергії та від внутрішньої енергії переробленого субстрату. В період 
термофільної фази компостування внутрішня енергія субстрату різко зростала, тоді як в період фази дозрівання, навпаки, - зменшувалася. Перероблений субстрат отримував лише близько $5 \%$ теплоти у вигляді внутрішньої енергії.

6. Близько $95 \%$ виробленої в процесі компостування теплоти виділялося в довкілля шляхом конвекції, теплового випромінювання та під час аерації. Втрати теплоти: через конвекцію $97 \%$ від загальних втрат; під час процесу змішування 3 одночасною аерацією - $2 \%$ від загальних втрат; втрати, пов'язані 3 мікрокліматом приміщень, - $1 \%$ від загальних втрат. Ці втрати можна значно зменшити, збільшивши ефективність ізоляції, або застосувавши додаткову систему підігріву реактора, наприклад, для холодного періоду року.

1. Arora S., Rani R., Ghosh S. Bioreactors in solid state fermentation technology: Design, applications and engineering aspects. Journal of Biotechnology. 2018. Vol. 269. Pp. 16-34. https://doi.org/10.1016/j.jbiotec.2018.01.010

2. Chia W.Y., Chew K.W., Le C.F., Lam S.S. et. al. Sustainable Utilization of Biowaste Compost for Renewable Energy and Soil Amendments. Environmental Pollution. 2020. Vol. 267. 115662. https://doi:10.1016/j.envpol.2020.115662

3. Clark C.S. Buckingham C.O. Bone D.H. Clark R.H. Laboratory scale composting: Techniques. Journal of Environmental Engineering Division. 1977. Vol. 103. Pp. 893-906.

4. Geethamani R., Soundara B., Kanmani S., Jayanthi V. et. al. Production of cost affordable organic manure using institutional waste by rapid composting method. Materials Today: Proceedings. 2020. Pp. 1-5.

https://doi.org/10.1016/j.matpr.2020.02.803

5. Golub G., Trehub M., Holubenko A., Tsyvenkova N., Chuba V., Tereshchuk M. Determining of the influence of reactor parameters on the uniformity of mixing substrate components. Eastern-European Journal of Enterprise Technologies. 2020. Vol. 6/7(108). Pp. 60-70.

https://doi.org/10.15587/1729-4061.2020.217159.

6. Graçaa J., Murphya B., Pentlavallic P., Allenc Ch.C.R., Bird E., Gaffney M., Duggan T., Kelleher B. Bacterium consortium drives compost stability and degradation of organic contaminants in in-vessel composting process of the mechanically separated organic fraction of municipal solid waste (MSOFMSW). Bioresource Technology Reports. 2021.

Vol. 13. 100621. https://doi.org/10.1016/j.biteb. 2020.100621

7. Kalamdhad A.S., Pasha M., Kazmi A.A. Stability evaluation of compost byrespiration techniques in a rotary drum composter. Resources, Conservationand Recycling. 2008.
Vol. 52(5). Pp. 829-834.

https://doi.org/10.1016/j.resconrec.2007.12.003

8. Kauser H., Pal S., Haq I., Khwairakpam M. Evaluation of rotary drum composting for the management of invasive weed Mikania micrantha Kunth and its toxicity assessment. Bioresource Technology. 2020. Vol. 313. 123678. https://doi.org/10.1016/j.biortech.2020.123678

9. Liu Z., Wang X., Wang F. The progress of composting technologies from static heap to intelligent reactor: Benefits and limitations. Journal of Cleaner Production. 2020.

Vol. 270. 122328. https://doi.org/10.1016/j.jclepro.2020.122328

10. Ryabchenko O., Golub G., Turčeková $N$. et al. Sustainable business modeling of circular agriculture production: Case study of circular bioeconomy. Journal of Security and Sustainability. 2017. Vol. 7(2). Pp. 301-309.

https://doi.org/10.9770/jssi.2017.7.2(10)

11. Varma V.S., Das S., Sastri C.V., Kalamdhad A.S. Microbial degradation of lignocellulosic fractions during drum composting of mixed organic waste. Sustainable Environment Research. 2017. Vol. 27(6). Pp. 265-272.

doi:10.1016/j.serj.2017.05.004

12. Vechera O., Tereshchuk M., Chuba V., Tsyvenkova $N$. Investigation of aerobic solid fraction fermentation process parameters for organic material. Engineering for rural development. 2020. Vol. 19. Pp. 1450-1455.

doi:10.22616/ERDev.2020.19.TF363

13. Xiong Zh.-Q., Wang G.-X., Huo Zh.-Ch., Yan L., et. $a l$. Effect of Aeration Rates on the Composting Process and Loss of Nitrogen during Composting. Applied Environmental Biotechnology. 2017. Vol. 2(2). Pp. 20-28. http://dx.doi.org/10.26789/AEB.2017.01.003

14. Васильковський О., Лещенко С., Васильковська К., Петренко Д. Підручник дослідника: навч. посіб. для студ. агротех. спец. Кіровоград. 2016. 204 с.

\section{REFERENCES}

1.Arora S., Rani R., Ghosh S. Bioreactors in solid state fermentation technology: Design, applications and engineering aspects. Journal of Biotechnology. 2018. Vol. 269. Pp. 16-34. https://doi.org/10.1016/j.jbiotec.2018.01.010

2. Chia W.Y., Chew K.W., Le C.F., Lam S.S. et. al. Sustainable Utilization of Biowaste Compost for Renewable Energy and Soil Amendments. Environmental Pollution. 2020. Vol. 267. 115662. https://doi:10.1016/j.envpol.2020.115662

3. Clark C.S. Buckingham C.O. Bone D.H. Clark R.H. Laboratory scale composting: Techniques. Journal of Environmental Engineering Division. 1977. Vol. 103. Pp. 893-906.

4. Geethamani R., Soundara B., Kanmani S., Jayanthi V. et. al. Production of cost affordable organic manure using institutional waste by rapid composting method. Materials Today: Proceedings. 2020. Pp. 1-5. https://doi.org/10.1016/j.matpr.2020.02.803

5. Golub G., Trehub M., Holubenko A., Tsyvenkova N., Chuba V., Tereshchuk M. Determining of the influence of reactor parameters on the uniformity of mixing substrate components. 
Eastern-European Journal of Enterprise Technologies. 2020. Vol. 6/7(108). Pp. 60-70.

https://doi.org/10.15587/1729-4061.2020.217159.

6. Graçaa J., Murphya B., Pentlavallic P., Allenc Ch.C.R., Bird E., Gaffney M., Duggan T., Kelleher B. Bacterium consortium drives compost stability and degradation of organic contaminants in in-vessel composting process of the mechanically separated organic fraction of municipal solid waste (MSOFMSW). Bioresource Technology Reports. 2021. Vol. 13. 100621. https://doi.org/10.1016/j.biteb.2020.100621

7. Kalamdhad A.S., Pasha M., Kazmi A.A. Stability evaluation of compost byrespiration techniques in a rotary drum composter. Resources, Conservationand Recycling. 2008. Vol. 52(5). Pp. 829-834.

https://doi.org/10.1016/j.resconrec.2007.12.003

8. Kauser H., Pal S., Haq I., Khwairakpam M. Evaluation of rotary drum composting for the management of invasive weed Mikania micrantha Kunth and its toxicity assessment. Bioresource Technology. 2020. Vol. 313. 123678. https://doi.org/10.1016/j.biortech.2020.123678

9. Liu Z., Wang X., Wang F. The progress of composting technologies from static heap to intelligent reactor: Benefits and limitations. Journal of Cleaner Production. 2020. Vol. 270. 122328. https://doi.org/10.1016/j.jclepro.2020.122328

10. Ryabchenko O., Golub G., Turčeková N. et al. Sustainable business modeling of circular agriculture production:
Case study of circular bioeconomy. Journal of Security and Sustainability. 2017. Vol. 7(2). Pp. 301-309.

https://doi.org/10.9770/jssi.2017.7.2(10)

11. Varma V.S., Das S., Sastri C.V., Kalamdhad A.S. Microbial degradation of lignocellulosic fractions during drum composting of mixed organic waste. Sustainable Environment Research. 2017. Vol. 27(6). Pp. 265-272.

doi:10.1016/j.serj.2017.05.004

12. Vechera O., Tereshchuk M., Chuba V., Tsyvenkova N. Investigation of aerobic solid fraction fermentation process parameters for organic material. Engineering for rural development. 2020. Vol. 19. Pp. 1450-1455.

doi:10.22616/ERDev.2020.19.TF363

13. Xiong Zh.-Q., Wang G.-X., Huo Zh.-Ch., Yan L., et. al. Effect of Aeration Rates on the Composting Process and Loss of Nitrogen during Composting. Applied Environmental Biotechnology. 2017. Vol. 2(2). Pp. 20-28. http://dx.doi.org/10.26789/AEB.2017.01.003

14. Vasylkovskyy O., Leshchenko S., Vasylkovska K., Petrenko D. Pidruchnyk doslidnyka: navch. posib. dlya stud. ahrotekh. spets.[Textbook of the researcher: textbook. way. for students. agrotech. special]. Kirovohrad. 2016. 204 p.

Стаття надійшла до редакції 03.03.21 Остаточна версія 16.03.21

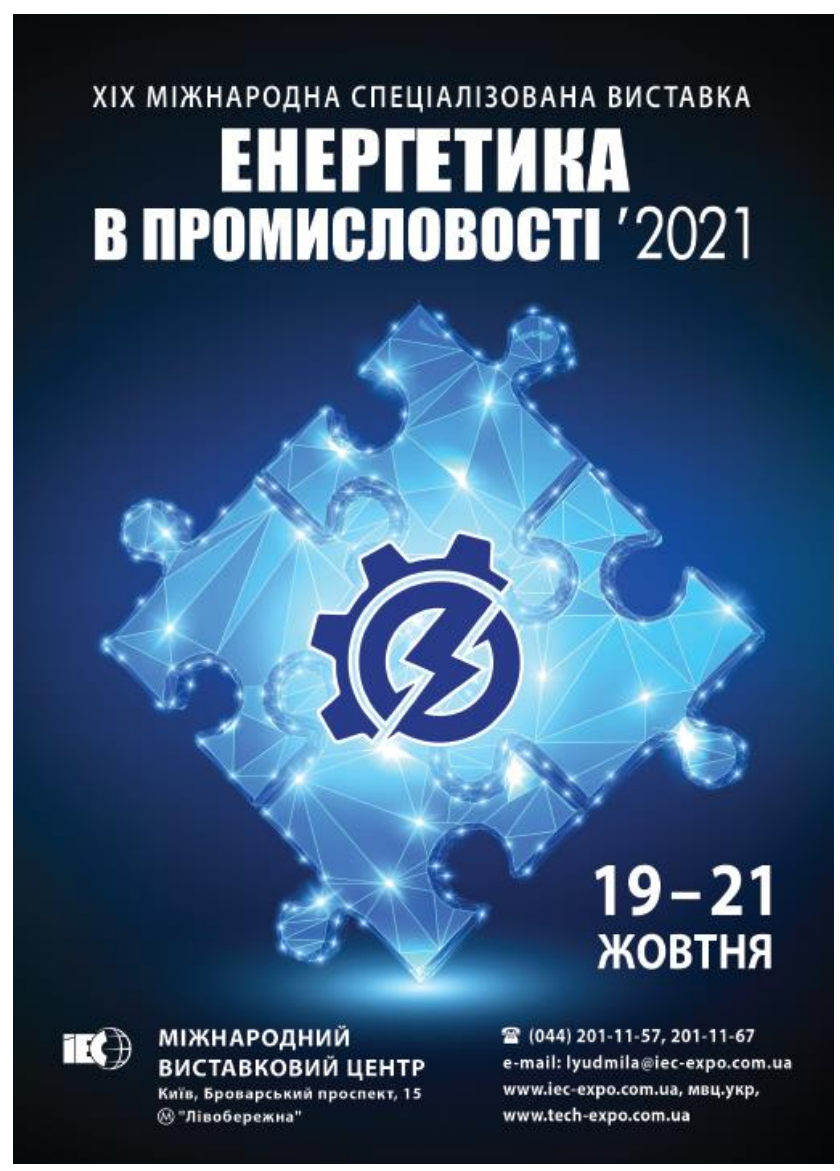

